\title{
MODEL PENGELOLAAN LINGKUNGAN DI KAWASAN PARIWISATA NUSA PENIDA, BALI
}

\author{
Nyoman Sudipa $^{1 *}$, Made Sudiana Mahendra'), Wayan Sandi Adnyana ${ }^{2)}$, Ida Bagus \\ Pujaastawa $^{3)}$ \\ ${ }^{1)}$ Program Studi Doktor Ilmu Lingkungan, Universitas Udayana \\ 2) Program Studi Agroteknologi, Universitas Udayana \\ 3) Program Studi Ilmu Budaya, Universitas Udayana \\ *email: nyoman_sudipa@yahoo.com
}

\section{ABSTRACT \\ ENVIRONMENTAL MANAGEMENT MODEL IN THE NUSA PENIDA TOURISM AREA, BALI}

As a regional income barn, the Nusa Penida Tourism Area needs to be managed comprehensively by involving all available resources, by encouraging new thinking about managing tourism that synergizes with environmental sustainability in the sustainable environment of the Nusa Penida Tourism Area. Tourism can increase economic growth but create a burden on the environment, so that Nusa Penida tourism becomes environmentally friendly tourism to support the development of green tourism. Progress in tourism impacts the environment, causes social and cultural changes in society, and impacts the carrying capacity of land and water from the massive tourism development in Nusa Penida. For this reason, it is necessary to formulate a model of environmental management that is relevant and has been developed. This study uses a systems approach with the Interpretative Structural Modeling (ISM) method to formulate an environmental management model in the Nusa Penida Tourism Area. This method can be used to help a group, in identifying contextual relationships between sub-elements of each element that forms a system based on ideas/structures or determinants in a complex problem (Saxena, 1992). The environmental management model in the Nusa Penida was formed based on government initiatives by involving all stakeholders as representatives of the Nusa Penida community and involving other elements such as non-government organizations and universities. In the management of the environment, institutional arrangements that specifically handle the environment and tourism of Nusa Penida must be formed with the government as the initiator and formed in a participatory manner. The recommended model of environmental management needs to be applied carefully and continued with the formation of institutions by involving the affected community sectors in Nusa Penida's environmental management and tourism.

Keywords: tourism; model; management; environment; Nusa Penida

\section{PENDAHULUAN}

Sebagai kawasan pariwisata, Nusa Penida masih belum dikelola secara optimal. Masih banyak sumber pendapatan dari pariwisata yang belum diakses karena keterbatasan manajemen pengelolaan. Dalam pengembangan pariwisata dibutuhkan sistem pengelolaan dan pengawasan lingkungan yang berbasis pada keseimbangan lingkungan hidup, kehidupan sosial dan budaya. Pariwisata bukan semata-mata mengejar keuntungan finansial tetapi berjalan seiring dengan peningkatan kualitas lingkungan hidup, peningkatan kesejahteraan dan pemerataan pendapatan dan pelestarian budaya masyarakat setempat. Perkembangan pariwisata di Nusa Penida menimbulkan dampak akumulatif apabila tidak 
dikembangkan model pengelolaan kawasan secara komprehensif.

Model pengeloaan lingkungan adalah formulasi objek yang disusun melalui perencanaan yang terstruktur. Dalam pengelolaan lingkungan setiap elemen berkewajiban menggunakan potensi secara arif dan menjaga keberlanjutan sumber daya lingkungan secara bijaksana (Basna et al., 2012). Penyusunan model pengelolaan lingkungan dapat dilakukan dengan mengidentifikasi parameter-parameter yang akan saling berkaitan. Pengelolaan lingkungan membutuhkan partisipasi masyarakat secara aktif didalamnya karena masyarakat menjadi subyek dalam pengelolaan lingkungan (Samadikun et al., 2012).

Model pengelolaan lingkungan yang baik akan berdampak kepada keberlanjutan pariwisata di Nusa Penida meliputi lingkungan eksternal, kapasitas pengelolaan dan kinerja lembaga pengelola yang berinteraksi dengan kelompok masyarakat secara partisipatif (Rosadi et al., 2016). Model pengelolaan lingkungan berkelanjutan dan harus didukung dengan pemberdayaan masyarakat yang efektif, menumbuhkan kepedulian lingkungan, meningkatkan ekonomi masyarakat (Wibisono, 2008). Pembangunan kawasan memperhatikan keterlibatan masyarakat untuk mengelola dampak yang ditimbulkan, baik dampak positif maupun dampak negatif (Jaya, 2007). Pelibatan masyarakat dalam pengelolaan pariwisata sangat penting seperti kasus di Nusa Penida. Sebagaian besar pariwisata Nusa Penida dibangun oleh masyarakat, maka dalam menyusun kebijakan pariwisata representasi masyarakat harus disertakan.

Untuk menyusun model Pengelolaan Lingkungan di Kawasan Pariwisata Nusa Penida dilakukan dengan mengidentifikasi hubungan antar sub elemen dari setiap elemen yang berdasarkan gagasan/ide sebagai penentu untuk memecahkan masalah (Saxena, 1992). Dalam menyusun elelem-elemen model pengelolaan lingkungan di Kawasan Pariwisata Nusa Penida dilakukan melalui diskusi, wawancara dengan para tokoh, pakar, pelaku dan penggiat pariwisata di Nusa
Penida. Sub elemen yang disusun mengadopsi atau menawarkan hasil rumusan daya dukung lingkungan (air dan tanah), dampak lingkungan dan dampak sosial budaya serta Sub elemen lainnya yang akan diperoleh melalui diskusi, wawancara dengan para tokoh, pakar, pelaku dan penggiat pariwisata di Nusa Penida.

Rumusan Model pengelolaan lingkungan di Kawasan Pariwisata Nusa Penida dibentuk berdasarkan inisiatif pemerintah dengan melibatkan seluruh pemangku kepentingan sebagai representasi masyarakat Nusa Penida dan melibatkan unsur lain seperti lembaga swadaya masyarakat dan perguruan tinggi. Dalam pengelolaan lingkungan wajib dibentuk kelembagaan yang khusus menangani lingkungan dan pariwisata Nusa Penida dengan pemerintah sebagai inisiator dan dibentuk secara partisipatif.

\section{METODOLOGI}

\subsection{Waktu Lokasi Penelitian}

Penelitian dilakukan di Kawasan Pariwisata Nusa Penida dengan titik koordinat $08^{\circ}$ 49'11" Lintang Selatan dan $115^{\circ} 35^{\prime} 13^{\prime}$ " Bujur Timur.

\subsection{Analisis Data}

Penelitian ini menggunakan pendekatan sistem dengan metode Interpretatif Structural Modelling (ISM) untuk merumuskan model pengelolaan lingkungan di Kawasan Pariwisata Nusa Penida. Metode ini dapat membantu untuk menyederhanakan suatu masalah dan dapat digunakan untuk mengidentifikasi hubungan kontekstual antar sub elemen. Beberapa kategori struktur dan kategori gagasan/ide yang mencerminkan hubungan kontekstual antar elemen dapat dikembangkan dengan memakai ISM (Kanungo et al., 2009). Dengan kata lain ISM merupakan sebuah perangkat untuk membantu menganalisis dalam mengambil keputusan yang rumit dengan cara mengelompokkan dan dituangkan dalam sebuah peta. Interpretative Structural Modeling (ISM) merupakan model matematis melalui pengkajian secara komprehensif 
untuk menggambarkan perihal yang kompleks teknik permodelan sistem (Pridaswara, 2009).

Dalam menyusun elelem-elemen model pengelolaan lingkungan di Kawasan Pariwisata Nusa Penida dilakukan melalui diskusi, wawancara dengan para tokoh, pakar, pelaku dan penggiat pariwisata di Nusa Penida. Sub elemen yang disusun mengadopsi atau menawarkan hasil rumusan daya dukung lingkungan (air dan tanah), dampak lingkungan dan dampak sosial budaya serta Sub elemen lainnya yang akan diperoleh melalui diskusi, wawancara dengan para tokoh, pakar, pelaku dan penggiat pariwisata di Nusa Penida dengan langkah-langkah sebagai berikut:

1. Identifikasi elemen-elemen sistem pengelolaan lingkungan di Kawasan Pariwisata Nusa Penida.

Kegiatan ini dapat dilakukan melalui penelitian, brainstorming, wawancara dan diskusi terfokus dengan stakeholder kunci. Ada 3 elemen dari 9 elemen yang akan dipilih yaitu (1) kebutuhan, (2) kendala atau permasalahan, (3) perubahan yang dimungkinkan, (4) tujuan, (5) tolok ukur dan indikator, (6) aktivitas/kegiatan yang dilakukan dalam rangka transformasi, (7) pelaku atau lembaga yang terlibat, (8) segmen masyarakat yang terpengaruh; dan efektivitas transformasi.

\section{Hubungan kontekstual antar elemen.}

Hubungan kontekstual antar elemen atau sub elemen ditetapkan sesuai dengan tujuan dari model yang akan dibangun. Sub elemen berasal dari masukan yang diperoleh melalui diskusi, wawancara dengan para tokoh. pakar, pelaku dan penggiat pariwisata di Nusa Penida. Sub elemen yang dipilih relevan dengan kondisi yang ada dan sesuai dengan model yang akan dibangun.

\section{Pembentukan Structural Self Interaction Matrix (SSIM).}

Matriks ini menggunakan empat macam simbol untuk menyajikan tipe hubungan yang ada adalah:

a) Simbol V untuk menyatakan adanya hubungan kontekstual antara elemen Ei terhadap elemen Ej atau elemen 1 dengan elemen 2 dan elemen berikutnya tetapi tidak sebaliknya.

b) Simbol A untuk menyatakan adanya hubungan kontekstual antara elemen Ej terhadap elemen Ei atau elemen 2 dengan elemen 1, elemen 3 dengan elemen 1 dan dengan elemen berikutnya, tetapi tidak sebaliknya.

c) Simbol $X$ untuk menyatakan adanya hubungan kontekstual secara timbal balik antara elemen Ei dengan elemen Ej.

d) Simbol O untuk menyatakan tidak adanya hubungan kontekstual antara elemen Ei dan elemen Ej.

\section{Reachability Matrix (RM)}

Matriks ini adalah matriks biner hasil konversi dari SSIM.

5. Pembuatan level partitioning.

Elemen-eleman diklasifikasikan kedalam level yang berbeda daristruktur ISM yang akan dibentuk.

6. Pembentukan canonical matrix dengan mengelompokkan elemen-elemen dengan level yang sama

7. Digraph melalui grafik yang berasal dari elemen-elemen yang saling berhubungan secara langsung, dan level hirarki.

8. Memberikan penjelasan dari elemenelemen sistem beserta alur hubungannya.

9. Untuk menguji hasil yang dirumuskan dalam model, dilakukan uji rumusan model dengan melakukan umpan balik kepada para tokoh. pakar, pelaku dan penggiat pariwisata di Nusa Penida.

\section{HASIL DAN PEMBAHASAN}

Kawasan pariwisata Nusa Penida yang sedang bertumbuh terus mengalami tekanan akibat masifnya pertumbuhan pembangunan sarana pariwisata dan sektor pendukung pariwisata. Lingkungan hidup mengalami dampak dari tekanan yang ditimbulkan oleh perkembangan pariwisata di Nusa Penida. Untuk menanggulangi dampak yang muncul perlu dirumuskan model pengelolaan lingkungan di Kawasan Pariwisata Nusa Penida. Elemen-elemen yang dipilih dalam menganalisis model pengelolaan lingkungan 
di Kawasan Pariwisata Nusa Penida adalah elemen-elemen penting yang berperan mempengaruhi pengelolaan Kawasan Pariwisata Nusa Penida. Dari 9 elemen yang dikembangkan oleh Saxena (1992), berdasarkan hasil wawancara dengan para tokoh, pakar, pelaku dan penggiat pariwisata di Nusa Penida, dipilih 5 elemen yang paling berpengaruh, yaitu (1) elemen kendala utama, (2) elemen tujuan program, (3) sektor masyarakat yang terpengaruhi, (4) perubahan yang diinginkan dan (5) elemen pelakuaatau lembaga yang terlibat dalam program.

\subsection{Elemen Kendala Utama}

Dari hasil diskusi dan wawancara dengan para tokoh, pakar, pelaku dan penggiat pariwisata di Nusa Penida terhadap pengelolaan lingkungan di Kawasan Pariwisata Nusa Penida diperoleh 9 sub elemen yaitu:

B1. masih rendahnya pemahaman masyarakat tentang pengelolaan lingkungan.

B2. kesadaran para pengusaha dan masyarakat masih rendah.

B3. pemberian sanksi dan penindakan belum tegas.

B4. penerapan aturan masih lemah.

B5. sumber daya manusia masih terbatas baik secara kualitas maupun kuantitas.

B6. koordinasi antar lembaga/instansi masih lemah.

B7. sistem pelayanan dan pencegahan kerusakan lingkungan masih lemah.

B8. dukungan dana masih lemah.

B9. sikap mental yang belum optimal.

Penilaian pakar terhadap hubungan konstektual antar sub elemen kendala utama dengan pendekatan $\mathrm{V}, \mathrm{A}, \mathrm{X}$ dan $\mathrm{O}$ dalam Gambar 1. Dari 9 sub elemen kendala utama yang menjadi sub elemen kunci adalah sumber daya manusia masih terbatas (5) dan dukungan dana masih lemah (8). Hal ini menunjukkan bahwa kendala utama dalam pengelolaan lingkungan adalah mendorong penguatan sumber daya manusia dan memberikan dukungan dana untuk mewujudkan sistem pencegahan kerusakan lingkungan dan didukung oleh menguatkan pemahaman masyarakat tentang pengelolaan lingkungan, meningkatkan kesadaran para pengusaha dan masyarakat masih rendah, pemberian sanksi dan penindakan dengan tegas, menguatkan penerapan aturan, memperkuat koordinasi antar lembaga/instansi, dan mengoptimalkan sikap mental dalam pengelolaan lingkungan.

\begin{tabular}{|c|c|c|c|c|c|c|c|c|c|}
\hline No. & B1 & B2 & B3 & B4 & B5 & B6 & B7 & B8 & B9 \\
\hline B1 & & V & $A$ & $A$ & 0 & 0 & $A$ & 0 & $A$ \\
\hline B2 & & & $\mathrm{V}$ & $\mathrm{V}$ & $A$ & 0 & A & 0 & $X$ \\
\hline B3 & & & & $X$ & 0 & $A$ & A & A & A \\
\hline B4 & & & & & $A$ & $X$ & $A$ & $A$ & 0 \\
\hline B5 & & & & & & 0 & V & 0 & 0 \\
\hline B6 & & & & & & & $A$ & 0 & A \\
\hline B7 & & & & & & & & A & 0 \\
\hline B8 & & & & & & & & & 0 \\
\hline B9 & & & & & & & & & \\
\hline
\end{tabular}

Gambar 1. Hubungan Konstektual antar Sub Elemen Kendala Utama

Disamping itu sub elemen sumber daya manusia masih terbatas (5) dan dukungan dana masih lemah (8) berdasarkan Driver Power dan Dependence berada di sektor IV (Independent), sub elemen tersebut juga mempunyai daya ungkit yang kuat terhadap elemen kendala utama. Sub elemen sistem pelayanan dan pencegahan kerusakan lingkungan masih lemah (7) juga mempunyai daya penggerak yang kuat terhadap elemen kendala utama tetapi kurang kuat dibandingkan dengan sub elemen sumber daya manusia masih terbatas (5) dan dukungan dana masih lemah (8). Sedangkan sub elemen (1) masih rendahnya pemahaman masyarakat tentang pengelolaan lingkungan, (2) kesadaran para pengusaha dan masyarakat masih rendah, (3) pemberian sanksi dan penindakan belum tegas, (4) penerapan aturan masih lemah, (6) koordinasi antar lembaga/instansi masih lemah, dan (9) sikap mental yang belum optimal berdasarkan Driver Power dan Dependence berada di sektor III (Linkages), sub elemen tersebut adalah sub elemen sensitif dan tidak stabil yang perlu kehati-hatian dalam mendukung elemen kendala utama dalam menyusun model pengelolaan lingkungan di Kawasan 
Pariwisata Nusa Penida. Komitmen memberikan dukungan pendanaan dalam pemerintah dan pelaku pariwisata sangat pengelolaan lingkungan di Kawasan diperlukan dalam pengembangan dan Pariwisata Nusa Penida (Gambar 2). penguatan sumber daya manusia dan

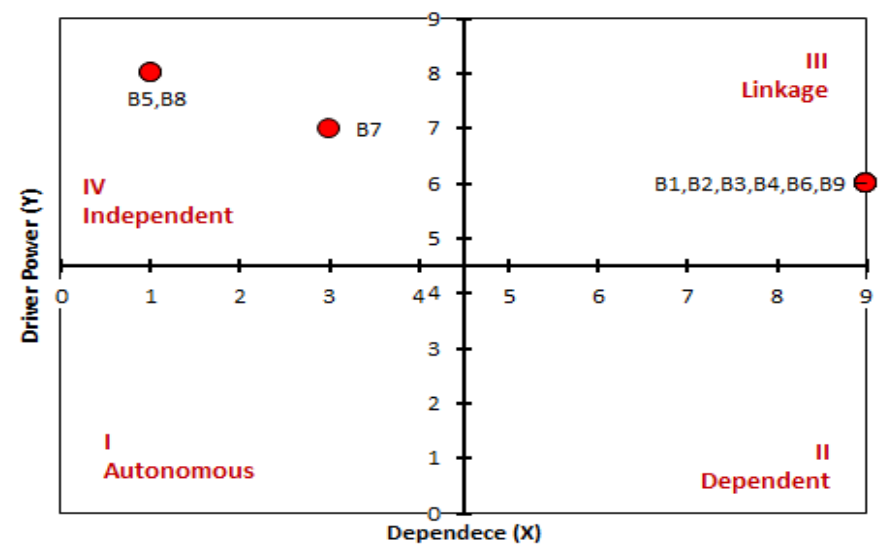

Gambar 2. Kuadran Hubungan Konstektual antar Sub Elemen Kendala Utama

Struktur model hirarki kendala utama model pengelolaan lingkungan di Kawasan Pariwisata Nusa Penida yang berdasarkan pengelompokan seperti pada Gambar 3. Sub elemen yang yang lebih tinggi mempunyai pengaruh kepada level yang lebih rendah

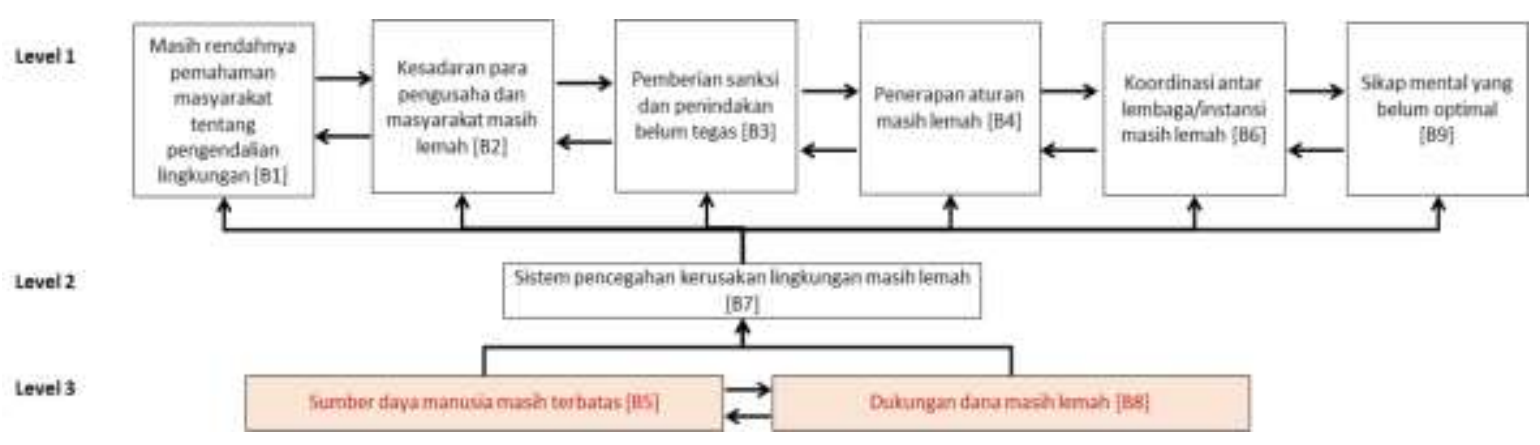

Gambar 3. Struktur Model Hirarki Kendala Utama

Dalam menyusun model pengelolaan lingkungan di Kawasan Pariwisata Nusa Penida khususnya dalam menganalisis kendala utama pengelolaan lingkungan bertumpu kepada peningkatan kualitas sumber daya manusia dan memberikan dukungan pendanaan dalam program pengelolaan lingkungan. Peningkatan kualitas sumber daya manusia dan memberikan dukungan pendanaan harus ditempatkan sebagai kunci utama untuk mendukung keberhasilan pelaksanaan dalam pengelolaan lingkungan. Sumber daya manusia yang dimaksudkan adalah sumber daya yang berasal dari masyarakat sebagai model pengelolaan lingkungan secara partisipatif dengan melibatkan multi sektor mulai dari pemerintah, masyarakat lokal, lembaga swadaya masyarakat, pengusuha dan dunia pendidikan dengan didukung sumber pendanaan yang jelas.

\subsection{Elemen Tujuan Program}

Dari hasil diskusi dan wawancara dengan para tokoh, pakar, pelaku dan penggiat pariwisata di Nusa Penida terhadap pengelolaan lingkungan di Kawasan Pariwisata Nusa Penida diperoleh 9 sub elemen yaitu:

G1. meningkatkan gairah investasi.

G2. meningkatkan kualitas lingkungan hidup.

G3. terjaganya daya dukung lingkungan hidup. 
G4. mengurangi alih fungsi lahan.

G5. meningkatkan pendapatan masyarakat.

G6. mengurangi biaya pengelolaan lingkungan hidup.

G7. mengubah perilaku dan kesadaran lingkungan.
G8. meningkatkan pendapatan asli daerah.

G9. pariwisata berkelanjutan.

Penilaian pakar terhadap hubungan konstektual antar sub elemen tujuan program dengan pendekatan $\mathrm{V}, \mathrm{A}, \mathrm{X}$ dan $\mathrm{O}$ dalam Gambar 4.

\begin{tabular}{|c|c|c|c|c|c|c|c|c|c|}
\hline No. & $\mathrm{G} 1$ & $\mathrm{G} 2$ & G3 & $\mathrm{G} 4$ & G5 & G6 & G7 & G8 & G9 \\
\hline $\mathrm{G} 1$ & & A & A & 0 & V & 0 & A & $\mathrm{V}$ & A \\
\hline G2 & & & V & A & V & V & A & V & A \\
\hline G3 & & & & $X$ & V & V & $A$ & V & $X$ \\
\hline G4 & & & & & 0 & 0 & $X$ & 0 & V \\
\hline G5 & & & & & & 0 & 0 & $\mathrm{~V}$ & A \\
\hline G6 & & & & & & & A & 0 & 0 \\
\hline G7 & & & & & & & & 0 & $x$ \\
\hline G8 & & & & & & & & & A \\
\hline G9 & & & & & & & & & \\
\hline
\end{tabular}

Gambar 4. Hubungan Konstektual antar Sub Elemen Tujuan Program

Hasil analisis terhadap 9 sub elemen tujuan program menunjukkan bahwa yang menjadi sub elemen kunci adalah meningkatkan kualitas lingkungan hidup (2), terjaganya daya dukung lingkungan hidup (3), mengurangi alih fungsi lahan (4), mengubah perilaku dan kesadaran lingkungan (7), dan pariwisata berkelanjutan (9). Walapun sebagai sub elemen kunci tetapi sub elemen ini berdasarkan Driver Power dan Dependence berada di sektor III (Linkage), yang berarti sub elemen tersebut sentitif dan tidak stabil sehingga perlu kehati-hatian dalam aplikasi menyusun model pengelolaan lingkungan di Kawasan Pariwisata Nusa Penida. Sub elemen meningkatkan gairah investasi (1), meningkatkan pendapatan masyarakat (5), mengurangi biaya pengelolaan lingkungan hidup (6), dan meningkatkan pendapatan asli daerah (8) merupakan sub elemen tidak bebas berdasarkan Driver Power dan Dependence berada di sektor II (Dependent), elemen ini berfungsi sebagai elemen pendukung tujuan program pengelolaan lingkungan (Gambar 5).

Struktur model hirarki tujuan program dalam menyusun model pengelolaan lingkungan di Kawasan Pariwisata Nusa Penida yang berdasarkan pengelompokan seperti pada Gambar 6. Sub elemen yang yang lebih tinggi mempunyai pengaruh kepada level yang lebih rendah.

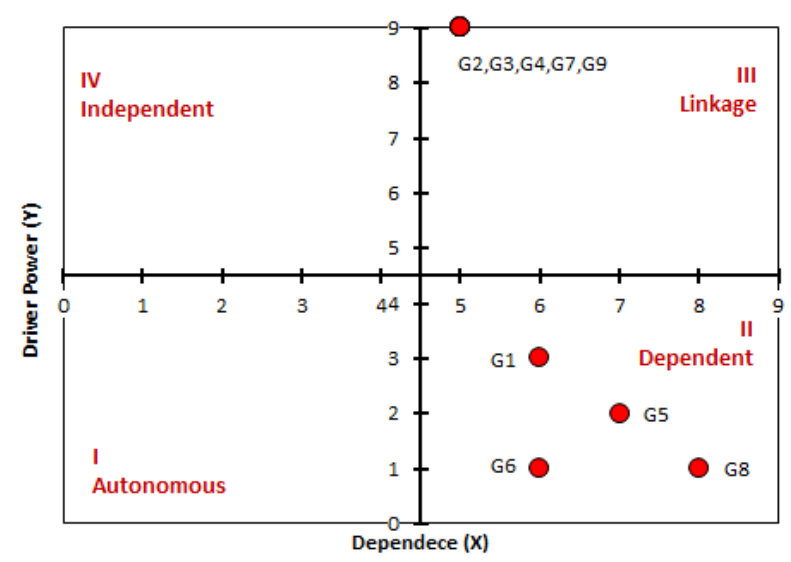

Gambar 5. Kuadran Hubungan Konstektual antar Sub Elemen Tujuan Program 


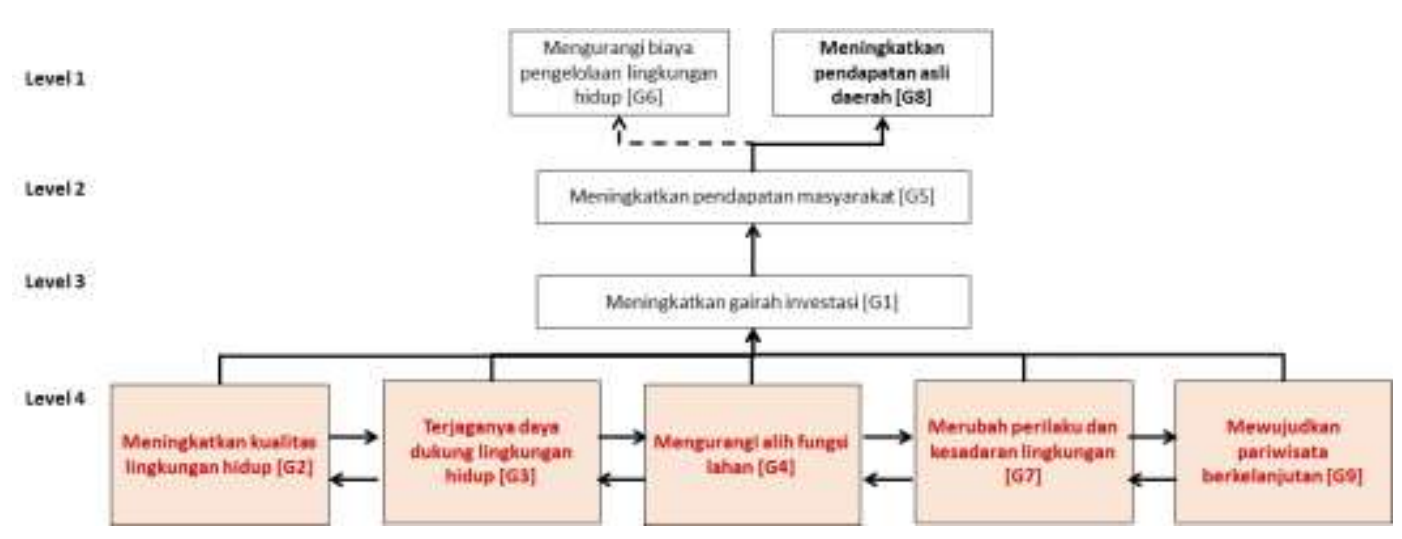

Grafik 6. Struktur Model Hirarki Tujuan Program

Dalam menyusun model pengelolaan lingkungan di Kawasan Pariwisata Nusa Penida khususnya dalam menganalisis tujuan program pengelolaan lingkungan harus menitik beratkan pada meningkatkan kualitas lingkungan hidup, terjaganya daya dukung lingkungan hidup, mengurangi alih fungsi lahan, merubah perilaku dan kesadaran lingkungan, dan pariwisata berkelanjutan. Dalam menerapkan tujuan program sebaiknya dilakukan dengan hati-hati, karena hal ini berhubungan dengan regulasi pemerintah. Pesatnya pertumbuhan pariwisata telah menimbulkan penurunan daya dukung lingkungan, alih fungsi lahan dan konlik sosial di Nusa Penida. Seperti sempadan pantai dan tanah negara di pinggir pantai hampir habis dibangun oleh investor dan masyarakat, padahal secara aturan tidak diperbolehkan. Kondisi ini jelas menurunkan kualitas lingkungan, menurunkan daya dukung lingkungan dan menimbulkan alih fungsi lahan.

Menerapkan kebijakan yang berhubungan dengan tujuan program pengelolaan sebaiknya dilakukan dengan melibatkan lintas sektor seperti pemerintah, masyarakat lokal, pengusaha, lembaga adat, lembaga swadaya masyarakat dan para pemerhati lingkungan. Muara dari tujuan program adalah kelembagaan untuk mengelola lingkungan di Kawasan Pariwisata Nusa Penida. Kelembagaan yang dibangun adalah kelembagaan yang mengakomodir semua pemangku kepentingan yang ujungnya untuk membangun pariwisata berkelanjuta di Nusa Penida. Model kelembagaan yang paling memungkinkan adalah badan layanan umum daerah (BLUD).

\subsection{Elemen Sektor Masyarakat yang Terpengaruhi}

Dari hasil diskusi dan wawancara dengan para tokoh, pakar, pelaku dan penggiat pariwisata di Nusa Penida terhadap pengelolaan lingkungan di Kawasan Pariwisata Nusa Penida diperoleh 11 sub elemen yaitu:

C1. pemerintah.

$\mathrm{C} 2$. pengusaha.

C3. lembaga swadaya masyarakat.

C4. masyarakat.

C5. mahasiswa/pelajar.

C6. lembaga adat.

C7. tokoh formal.

C8. wisatawan.

C9. pemuda dan remaja.

C10. perguruan tinggi

C11. pemerhati lingkungan/relawan

Penilaian pakar terhadap hubungan konstektual antar sub elemen sektor masyarakat yang terpengaruhi dengan pendekatan V, A, X dan O dalam Gambar 7. Hasil analisis terhadap 9 sub elemen sektor masyarakat yang terpengaruhi menunjukkan bahwa yang menjadi sub elemen kunci adalah pemerintah (1) karena berdasarkan Driver Power dan Dependence berada di sektor IV (Independent), yang berarti sub elemen tersebut juga mempunyai daya ungkit dan daya penggerak yang kuat terhadap elemen elemen sektor masyarakat yang terpengaruhi. Sub elemen pengusaha (2) juga 
berada di sektor IV (Independent), tetapi sub elemen pemerintah lebih kuat (Gambar 8).

\begin{tabular}{|c|c|c|c|c|c|c|c|c|c|c|c|}
\hline No. & C1 & C2 & C3 & C4 & C5 & C6 & C7 & C8 & C9 & C10 & C11 \\
\hline $\mathrm{C} 1$ & & V & $\mathrm{V}$ & V & $\mathrm{V}$ & V & V & V & V & V & V \\
\hline $\mathrm{C} 2$ & & & 0 & $\mathrm{~V}$ & 0 & V & $\mathrm{V}$ & $\mathrm{V}$ & 0 & 0 & 0 \\
\hline C3 & & & & V & 0 & V & V & 0 & V & A & $X$ \\
\hline $\mathrm{C} 4$ & & & & & $A$ & $x$ & $x$ & $\mathrm{~V}$ & $x$ & A & A \\
\hline C5 & & & & & & V & $\mathrm{V}$ & 0 & $x$ & $x$ & A \\
\hline C6 & & & & & & & $x$ & $\mathrm{~V}$ & V & A & A \\
\hline $\mathrm{C7}$ & & & & & & & & $A$ & $x$ & A & A \\
\hline $\mathrm{C} 8$ & & & & & & & & & A & A & A \\
\hline $\mathrm{CP}$ & & & & & & & & & & $X$ & A \\
\hline C10 & & & & & & & & & & & $x$ \\
\hline C11 & & & & & & & & & & & \\
\hline
\end{tabular}

Gambar 7. Hubungan Konstektual antar Sub Elemen Sektor Masyarakat yang Terpengaruhi

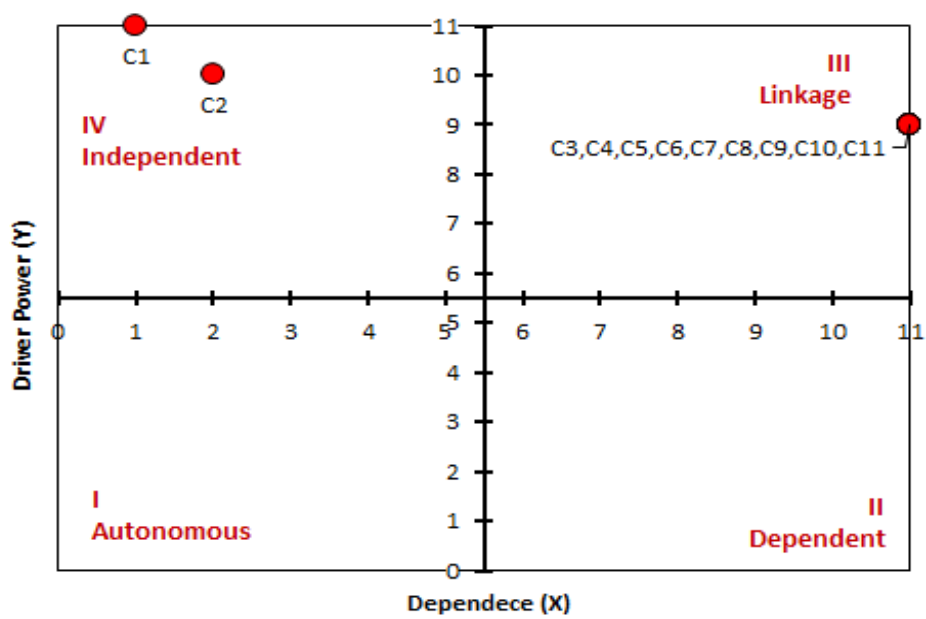

Gambar 8. Kuadran Hubungan Konstektual antar Sub Elemen Sektor Masyarakat yang Terpengaruhi

Sub elemen lembaga swadaya masyarakat (3), masyarakat (4), mahasiswa/pelajar (5), lembaga adat (6), tokoh formal (7), wisatawan (8), pemuda dan remaja (9), perguruan tinggi (10), dan pemerhati lingkungan/relawan (11) berdasarkan Driver Power dan Dependence berada di sektor III (Linkage), yang berarti sub elemen tersebut sentitif dan tidak stabil sehingga perlu kehati-hatian dalam aplikasi menyusun model pengelolaan lingkungan di Kawasan Pariwisata Nusa Penida.

Struktur model hirarki sektor masyarakat yang terpengaruhi dalam menyusun model pengelolaan lingkungan di Kawasan Pariwisata Nusa Penida yang berdasarkan pengelompokan seperti pada Gambar 9. Sub elemen yang yang lebih tinggi mempunyai pengaruh kepada level yang lebih rendah. 


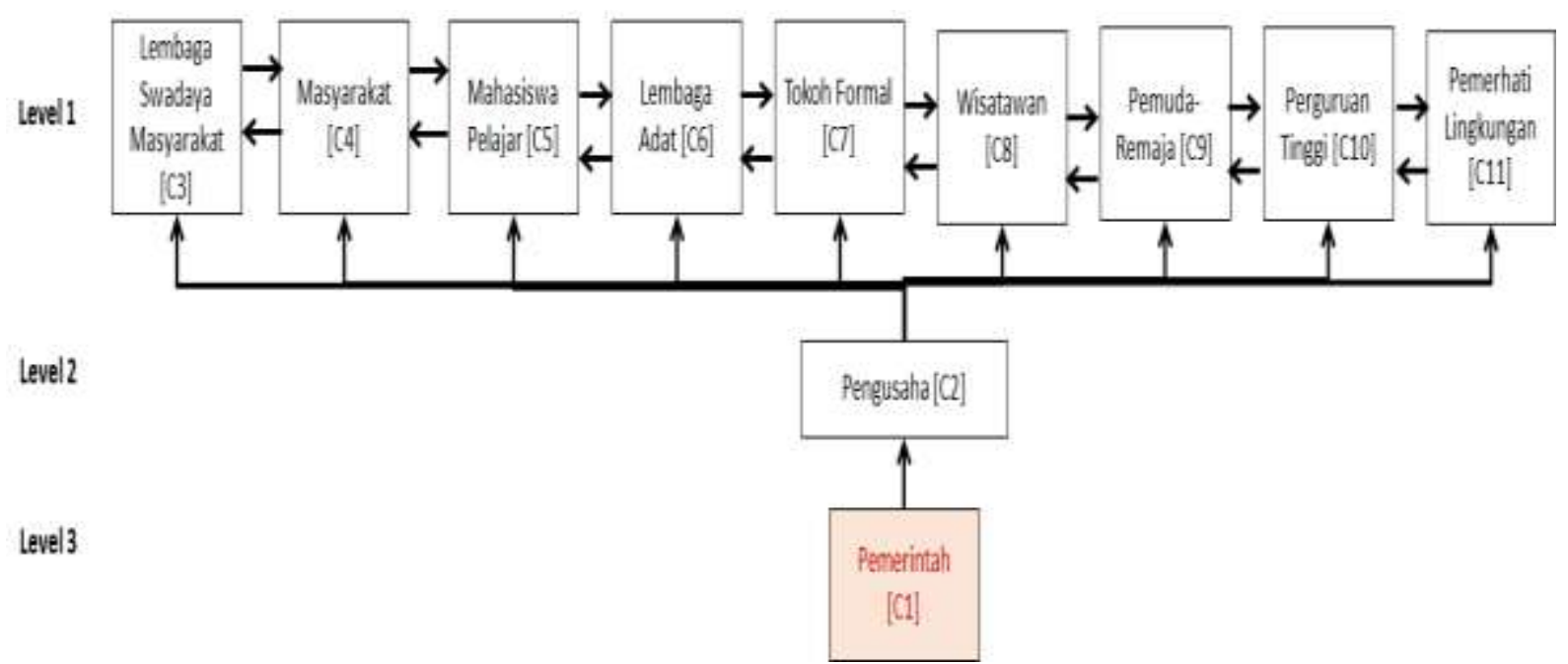

Grafik 9. Struktur Model Hirarki Sektor Masyarakat yang Terpengaruhi

Dalam menyusun model pengelolaan lingkungan di Kawasan Pariwisata Nusa Penida khususnya dalam menganalisis sektor masyarakat yang terpengaruhi dalam pengelolaan lingkungan adalah pemerintah dan pengusaha. Tetapi posisi pemerintah lebih kuat dan merupakan kunci penggerakan utama dalam menyusun model pengelolaan lingkungan di Kawasan Pariwisata Nusa Penida. Pemerintah yang dimaksud adalah Pemerintah Daerah Kabupaten Klungkung. Pemerintah Daerah Kabupaten Klungkung harus menjadi motor utama dan menjadi inisiator dalam menyusun model pengelolaan lingkungan di Kawasan Pariwisata Nusa Penida, karena pemerintah memegang regulasi, kebijakan, memiliki sumber daya manusia dan mempunyai kewenangan untuk membagun kelembagaan.

Inisiatif model pengelolaan lingkungan dimulai dengan melakukan pendekatanpendekatan formal dan informal dengan sektor masyarakat yang berpengaruh dan dilanjutkan dengan membentuk model kelembagaan formal sebagai bentuk komitmen dalam mengelola lingkungan. Model kelembagaan yang akan dibangun merujuk kepada tata aturan pemerintah yang mengakomodir peran serta pemerintah, masyarakat, lembaga swadaya masyarakat, pengusaha, lembaga adat, dll.

\subsection{Elemen Perubahan yang Diinginkan}

Dari hasil diskusi dan wawancara dengan para tokoh, pakar, pelaku dan penggiat pariwisata di Nusa Penida terhadap pengelolaan lingkungan di Kawasan Pariwisata Nusa Penida diperoleh 8 sub elemen yaitu:

E1. kebersihan dan kesehatan lingkungan terjaga.

E2. berkurangnya pelanggaran lingkungan.

E3. terbentuk kemitraan lingkungan.

E4. pengelolaan pariwisata dan lingkungan berkelanjutan.

E5. berkurangnya biaya operasional pengelolaan lingkungan.

E6. meningkatnya kesadaran pengusaha dan masyarakat.

E7. meningkatnya investasi.

E8. meningkatnya pendapatan asli daerah.

Penilaian pakar terhadap hubungan konstektual antar sub elemen perubahan yang diinginkan dengan pendekatan $\mathrm{V}, \mathrm{A}, \mathrm{X}$ dan $\mathrm{O}$ dalam Gambar 10. Hasil analisis terhadap 8 sub elemen tujuan program menunjukkan bahwa yang menjadi sub elemen kunci adalah kebersihan dan kesehatan lingkungan terjaga (1), berkurangnya pelanggaran lingkungan (2), terbentuk kemitraan lingkungan (3), pengelolaan pariwisata dan lingkungan berkelanjutan (4), meningkatnya kesadaran pengusaha dan masyarakat (6). Walapun sebagai sub elemen kunci tetapi sub elemen ini berdasarkan Driver Power dan Dependence berada di sektor III (Linkage), yang berarti sub elemen tersebut sentitif dan tidak stabil sehingga perlu kehati-hatian dalam aplikasi menyusun model pengelolaan lingkungan di Kawasan Pariwisata Nusa Penida. Sedangkan sub lemen meningkatkan gairah investasi berkurangnya biaya 
operasional pengelolaan lingkungan (5), berada di sektor II (Dependent), elemen ini meningkatnya investasi (7), dan berfungsi sebagai elemen pendukung tujuan meningkatnya pendapatan asli daerah (8) program pengelolaan lingkungan (Gambar merupakan sub elemen tidak bebas berdasarkan Driver Power dan Dependence $11)$.

\begin{tabular}{|c|c|c|c|c|c|c|c|c|}
\hline No. & E1 & E2 & E3 & E4 & E5 & E6 & E7 & E8 \\
\hline E1 & & $x$ & $A$ & $x$ & 0 & $A$ & $\mathrm{~V}$ & $\mathrm{~V}$ \\
\hline E2 & & & A & A & 0 & $X$ & V & 0 \\
\hline E3 & & & & A & 0 & A & $\mathrm{V}$ & 0 \\
\hline E4 & & & & & V & $\mathrm{V}$ & V & V \\
\hline E5 & & & & & & 0 & 0 & 0 \\
\hline E6 & & & & & & & $\mathrm{V}$ & $\mathrm{V}$ \\
\hline E7 & & & & & & & & V \\
\hline E8 & & & & & & & & \\
\hline
\end{tabular}

Gambar 10. Hubungan Konstektual antar Sub Elemen Perubahan yang Diinginkan

Struktur model hirarki sektor berdasarkan pengelompokan tertera pada masyarakat yang terpengaruhi dalam Gambar 12. Sub elemen yang yang lebih menyusun model pengelolaan lingkungan di tinggi mempunyai pengaruh kepada level Kawasan Pariwisata Nusa Penida yang yang lebih rendah.

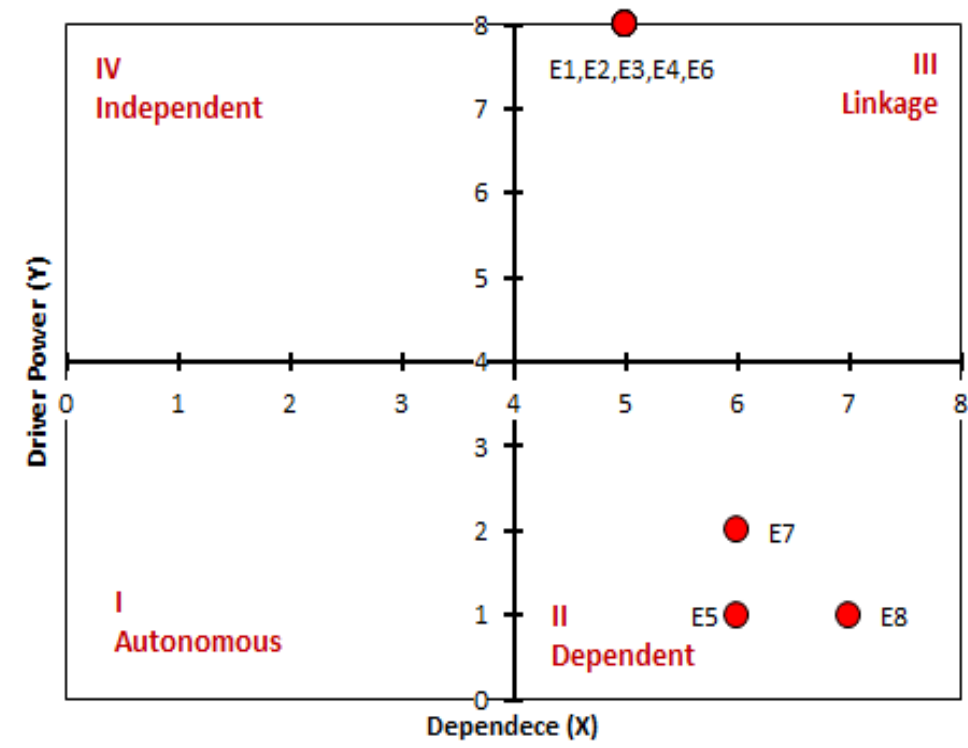

Gambar 11. Kuadran Hubungan Konstektual antar Sub Elemen Perubahan yang Diinginkan

Dalam menyusun model pengelolaan lingkungan di Kawasan Pariwisata Nusa Penida khususnya dalam menganalisis perubahan yang diingikan pengelolaan lingkungan dititik-beratkan pada kebersihan dan kesehatan lingkungan, berkurangnya pelanggaran lingkungan, terbentuk kemitraan lingkungan, pengelolaan pariwisata dan lingkungan berkelanjutan, meningkatnya kesadaran pengusaha dan masyarakat, tetapi 
dalam penerapannya dilakukan dengan hatihati karena sub elemen tersebut sensitif dan tidak stabil. Pokok-pokok kegiatan yang dilakukan adalah menciptakan perubahanperubahan dan meningkatkan kesadaran bersama akan lingkungan yang bersih dan sehat, mengurangi lingkungan, menjalin kemitraan antar pemangku kepentingan dan mengelola lingkungan secara berkelanjutan.

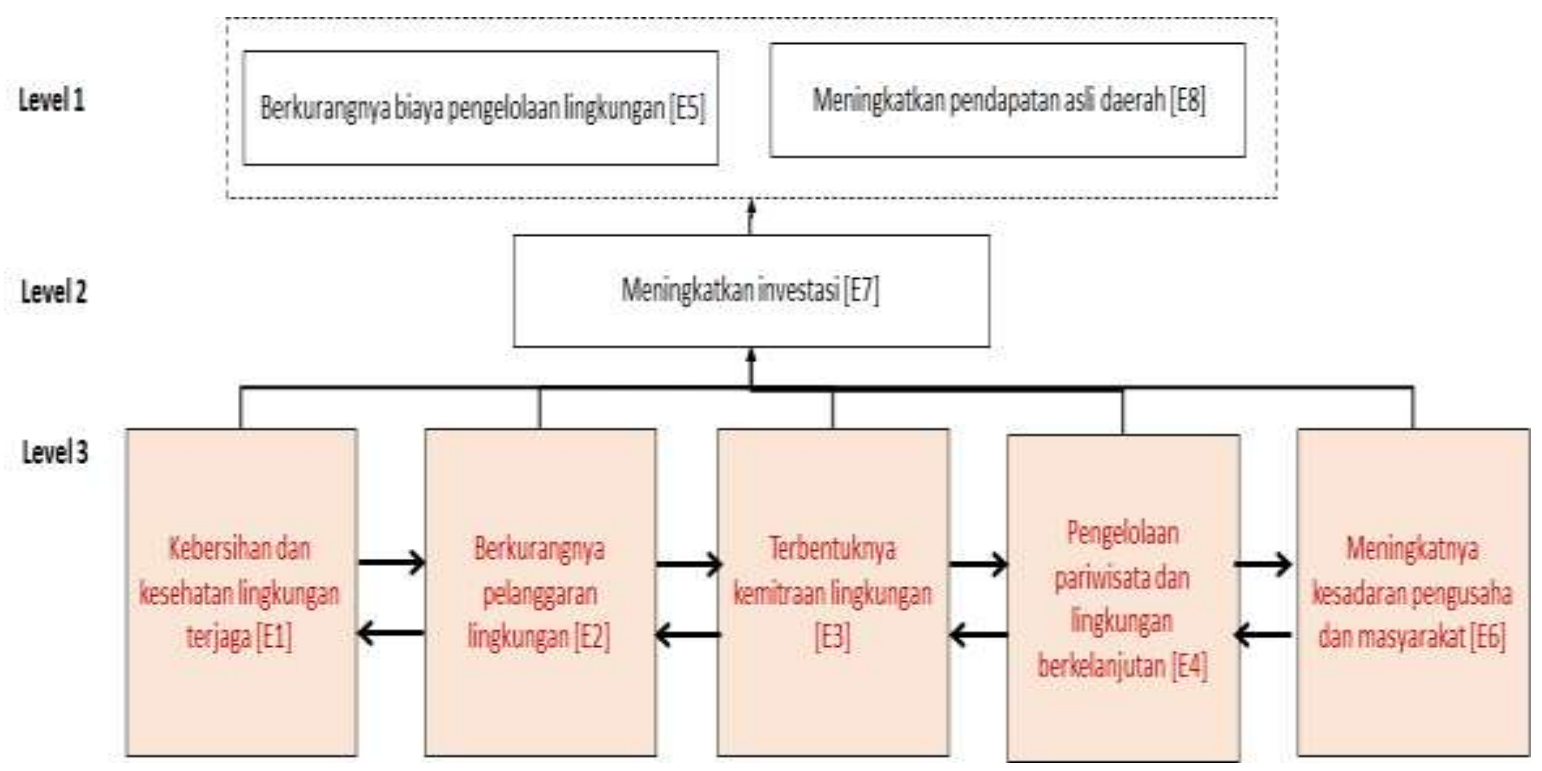

Grafik 12. Struktur Model Hirarki Perubahan yang Diinginkan

Sub elemen kunci dari elemen perubahan yang diingikan yaitu kebersihan dan kesehatan lingkungan terjaga (1), berkurangnya pelanggaran lingkungan (2), terbentuk kemitraan lingkungan (3), pengelolaan pariwisata dan lingkungan berkelanjutan (4), meningkatnya kesadaran pengusaha dan masyarakat (6), bisa dijadikan sebagai misi dalam pembetukan kelembagaan pengelolaan lingkungan di Kawasan Pariwisata Nusa Penida. Sub elemen tersebut perlu didiskusikan lebih lanjut dengan lintas sektor untuk mencapai kesepakatan bersama.

Berdasarkan elemen-elemen dan sub elemen kunci dapat dirumuskan gambaran model pengelolaan lingkungan di Kawasan Pariwisata Nusa Penida seperti pada Gambar 13. Model pengelolaan lingkungan di Kawasan Pariwisata Nusa Penida dibentuk berdasarkan inisiatif pemerintah dengan melibatkan seluruh pemangku kepentingan sebagai representasi masyarakat Nusa Penida dan melibatkan unsur lain seperti lembaga swadaya masyarakat dan perguruan tinggi. Dalam pengelolaan lingkungan wajib dibentuk kelembagaan yang khusus menangani lingkungan dan pariwisata Nusa Penida dengan pemerintah sebagai inisiator dan dibentuk secara partisipatif. 


\begin{tabular}{|c|c|}
\hline $\begin{array}{c}\text { Kelembagaan } \\
\text { (Partisipatif) }\end{array}$ & $\begin{array}{c}\text { Inisiator } \\
\text { Pemerintah }\end{array}$ \\
\hline $\begin{array}{l}\text { Kendala Utama (masalah) } \\
\text { 1. Sumber daya manusia masih terbatas } \\
\text { dan dukungan dana masih lemah (sub } \\
\text { elemen kunci) } \\
\text { 2. Sistem pelayanan dan pencegahan } \\
\text { kerusakan lingkungan masih lemah (sub } \\
\text { elemen kunci tetapi kurang kuat) } \\
\text { 3. Masih rendahnya pemahaman } \\
\text { masyarakat tentang pengelolaan } \\
\text { lingkungan, kesadaran para pengusaha } \\
\text { dan masyarakat masih rendah, } \\
\text { pemberian sanksi dan penindakan } \\
\text { belum tegas, penerapan aturan masih } \\
\text { lemah, koordinasi antar } \\
\text { lembaga/instansi masih lemah, dan } \\
\text { sikap mental yang belum optimal } \\
\text { (Sensitif dan tidak stabil) }\end{array}$ & $\begin{array}{l}\text { Perubahan yang Diinginkan (Misi) } \\
\text { 1. Kebersihan dan kesehatan } \\
\text { lingkungan terjaga, berkurangnya } \\
\text { pelanggaran lingkungan, terbentuk } \\
\text { kemitraan lingkungan, pengelolaan } \\
\text { pariwisata dan lingkungan } \\
\text { berkelanjutan, meningkatnya } \\
\text { kesadaran pengusaha dan } \\
\text { masyarakat (sub elemen kunci) } \\
\text { 2. Berkurangnya biaya operasional } \\
\text { pengelolaan lingkungan, } \\
\text { meningkatnya investasi, dan } \\
\text { meningkatnya pendapatan asli } \\
\text { daerah (sub elemen pendukung) }\end{array}$ \\
\hline
\end{tabular}

Gambar 13. Model Pengelolaan Lingkungan

Badan hukum yang memungkinkan dengan meibatkan lintas sektor adalah badan layanan umum daerah (BLUD) dengan dibentuk bagian-bagian sebagai operasional di lapangan. Dalam menjalankan fungsi pengelolaan lingkungan dan pariwisata, lembaga yang dibangun harus mengenali kendala utama atau masalah yang dihadapi sebagai berikut:
1. Sumber daya manusia masih terbatas dan dukungan dana masih lemah (sub elemen kunci).

2. Sistem pelayanan dan pencegahan kerusakan lingkungan masih lemah (sub elemen kunci tetapi kurang kuat).

3. Masih rendahnya pemahaman masyarakat tentang pengelolaan lingkungan, kesadaran para pengusaha dan masyarakat masih rendah, pemberian sanksi dan 
penindakan belum tegas, penerapan aturan masih lemah, koordinasi antar lembaga/instansi masih lemah, dan sikap mental yang belum optimal (sensitif dan tidak stabil).

Kendala utama atau masalah tersebut harus ditanggulangi dengan melakukan penguatan kelembagaan, penguatan sumber daya manusia dan sumber dukungan dana dari Pemerintah Daerah Kabupaten Klungkung atau kelembagaan yang dibentuk secara mandiri mendanai dirinya sendiri dengan sumber pendanaan dari hasil pengelolaan kawasan. Memperkuat pemahaman masyarakat dengan melakukan sosialisasi, pelatihan pembinaan dan pendampingan, meningkatkan koordinasi antar organisasi perangkat daerah dalam penegakan aturan dan penindakan pelanggaran lingkungan.

\section{SIMPULAN DAN SARAN}

\subsection{Simpulan}

Model pengelolaan lingkungan di Kawasan Pariwisata Nusa Penida dibentuk berdasarkan inisiatif pemerintah dengan melibatkan seluruh pemangku kepentingan sebagai representasi masyarakat Nusa Penida dengan membentuk kelembagaan yang khusus menangani lingkungan dan pariwisata Nusa Penida dengan pemerintah sebagai inisiator dan dibentuk secara partisipatif dalam pengelolaan lingkungan di Kawasan Pariwisata Nusa Penida.

\subsection{Saran}

Model pengelolaan lingkungan yang telah direkomendasikan perlu diterapkan secara hati-hati dan dilanjutkan dengan pembentukan kelembagaan dengan melibatkan sektor masyarakat yang terpengaruhi dalam pengelolaan lingkungan dan pariwisata Nusa Penida.

\section{DAFTAR PUSTAKA}

Basna, N., Marsono, D., Gunawan, T., Irham. 2012. Model Pengelolaan Lingkungan Taman Wisata Alam Gunung Meja Manokwari Papua Barat; Vo. 19. No.
3: pp 274-280. Jurnal Manusia dan Lingkungan.

Jaya, I. 2007. "Pengelolaan Lingkungan Kawasan Wisata Danau Lebo Kecamatan Taliwang Kabupaten Sumbawa Barat" (tesis). Semarang. Universitas Diponegoro.

Kanungo S dan V.V. Batnagar, 2002. Beyond Generic Models for Information System Quality : The Use of Interpretative Structural Modelling (ISM); Vol. 19: pp 531:549. Journal of System Research and Behavior Science.

Pridaswara. 2009. Model Kerangka Keja Supply Chain dengan Menggunakan Metode Interpretative Structural Modeling (ISM). Jakarta. Universitas Indonesia: p 25-31.

Rosadi, Purwanto M. Y. J, Sutjahyo S. H, Pramudya B. 2016. Sistem Pengembangan Kelembagaan Agroindustri Padi Skala Kecil dan Menengah; Vol. 8. No. 2: pp 1-11. Jurnal Sosial Ekonomi Pekerjaan Umum.

Samadikun, B., P., Sudibyakto, Setiawan, B., Rijanta. 2012. Model Perencanaan dan Pengelolaan Lingkungan (Kasus; Bentang Lahan Kawasan Tembalang Semarang); Vol. 9. No. 1: pp 17-20. Jurnal Presipitasi.

Saxena, J. P. 1992. Hierarchy and Classification of Program Plan Element Using Interpretative Structural Modelling; 12 (6): P 651:670. Systems Practice.

Wibisono, B. 2008. "Model Kebijakan Pengelolaan Lingkungan Pertambangan Mineral yang Berkelanjutan (Studi Kasus: Pengelolaan Lingkungan Mod-ADA di Kabupaten Mimika Papua)" (disertasi). Bogor. Institut Pertanian Bogor. 